\title{
Sodium-dependent succinate decarboxylation by a new anaerobic bacterium belonging to the genus Peptostreptococcus
}

\author{
Peter H. Janssen ${ }^{1,2,3, *}$, Werner Liesack ${ }^{3}$, Claudia Kluge ${ }^{4}$, Sabine Seeliger ${ }^{2}$, \\ Bernhard Schink ${ }^{2} \&$ \& Chris G. Harfoot ${ }^{1}$ \\ ${ }^{1}$ Department of Biological Sciences, University of Waikato, Hamilton, New Zealand; ${ }^{2}$ Fakultät für Biologie, \\ Universität Konstanz, Konstanz, Germany; ${ }^{3}$ Max-Planck-Institut fïr Terrestrische Mikrobiologie, Marburg, \\ Germany; ${ }^{4}$ Mikrobiologisches Institut, Eidgenössische Technische Hochschule, ETH-Zentrum, Zürich, \\ Switzerland (* author for correspondence: Department of Microbiology, University of Melbourne, Parkville, \\ Victoria 3052, Australia)
}

Received 21 August 1995; accepted in final form 24 November 1995

Key words: anaerobic degradation, energetics, methylmalonyl-CoA decarboxylase, Peptostreptococcus, sodiumdependent energy conservation, succinate

\begin{abstract}
An anaerobic bacterium was isolated from a polluted sediment, with succinate and yeast extract as carbon and energy sources. The new strain was Gram-positive, the cells were coccal shaped, the mol\% $\mathrm{G}+\mathrm{C}$ content of the genomic DNA was 29 , and the peptidoglycan was of the L-ornithine-D-glutamic acid type. Comparative sequence analysis of the 16S rRNA gene showed the new strain to belong to the genus Peptostreptococcus. Succinate, fumarate, pyruvate, 3-hydroxybutyrate and lysine supported growth. Succinate was degraded to propionate and presumably $\mathrm{CO}_{2}$, with a stoichiometric cell yield. Key enzymes of the methylmalonyl-CoA decarboxylase pathway were present. The methylmalonyl-CoA decarboxylase activity was avidin-sensitive and sodium dependent, and about $5 \mathrm{mM} \mathrm{Na}^{+}$was required for maximal activity. Whole cells, however, required at least $50 \mathrm{mM}$ sodium for maximal succinate decarboxylation activity and to support the maximum growth rate. Sodium-dependent energy conservation coupled to succinate decarboxylation is shown for the first time to occur in a bacterium belonging to the group of Gram-positive bacteria containing the peptostreptococci and their relatives.
\end{abstract}

\section{Introduction}

Succinate degradation under anoxic conditions by Propionigenium modestum has been studied in some detail. The growth (Schink \& Pfennig 1982) and metabolism (Hilpert et al. 1984) of $P$. modestum are sodium dependent. The energy metabolism is based on a sodium-translocating methylmalonyl-CoA decarboxylase which generates a sodium-motive force, which is then used to generate ATP via a membrane-bound adenosinetriphosphatase (ATPase) (Hilpert et al. 1984, Laubinger \& Dimroth 1988). Although the ATPase of $P$. modestum is able to pump protons (Laubinger \& Dimroth 1989), its physiological role is sodium translocation (Hilpert et al. 1984; Laubinger \& Dimroth 1988). The methylmalonyl-CoA decarboxylase and ATPase require approximately $1 \mathrm{mM}$ and $2 \mathrm{mM}$ $\mathrm{Na}^{+}$for maximal activity, respectively (Hilpert et al. 1984). The minimum requirement for growth is 100 $150 \mathrm{mM} \mathrm{NaCl}$ (Schink 1992). Propionigenium spp. (Schink \& Pfennig 1982, Janssen \& Liesack 1995) are related to Fusobacterium nucleatum, which catalyzes a sodium-dependent decarboxylation of glutaconyl$\mathrm{CoA}$, an intermediate of glutamate catabolism, to generate a transmembrane sodium gradient able to be utilized by the bacterium for ATP generation (Beatrix et al. 1990). Propionigenium spp. and Fusobacterium spp. belong to cluster XIX of Collins et al. (1994).

The decarboxylation of succinate can also generate metabolic energy in a range of other bacteria belonging to the group of Gram-positive bacteria with a Gramnegative cell wall structure. These include Sporomusa 
spp. (Ollivier et al. 1985, Breznak et al. 1988, Dehning et al. 1989), Selenomonas spp. (Guangsheng et al. 1992, Schleifinger \& Wolin 1973), Phascolarctobacterium faecium (Osawa et al. 1992, Del Dot et al. 1993), Succiniclasticum ruminis (van Gylswyk 1995), and Veillonella parvula (Janssen 1992, Willems \& Collins 1995). Phylogenetically, these bacteria belong to cluster IX of Collins et al. (1994). Some of these organisms are only able to utilize succinate as a supplementary energy source, and cannot grow with succinate as the sole energy source.

In this communication we report on the isolation and characteristics of a succinate-decarboxylating bacterium which does not belong to these two phylogenetic groups, but represents a new taxon within another radiation of the Gram-positive bacteria, typified by the peptostreptococci [cluster XIII of Collins et al. (1994)]. Succinate decarboxylation and the ability to grow with this reaction has not been previously reported within this group.

\section{Materials and methods}

\section{Isolation and characterization}

The estuarine and freshwater media used in this study have been described (Janssen \& Harfoot 1990). Unless noted otherwise, $\mathrm{L}$-isomers of organic and amino acids, and D-isomers of sugars were used. For all cultures other than enrichments, sulfide reductant (Janssen \& Harfoot 1990) was used. Enrichment media contained cysteine/sulfide reductant (Janssen \& Harfoot 1990). The agar deep method for isolating pure cultures was described by Pfennig (1978). Estuarine cooked meat medium consisted of commercial cooked meat medium (Difco, Detroit, Michigan, USA) supplemented with $15 \mathrm{~g} \mathrm{NaCl}$ per litre. All incubations were at $34{ }^{\circ} \mathrm{C}$ unless otherwise noted.

The amino acid stock solution of Hudson et al. (1989) with the addition of $0.8 \mathrm{~g}$ L-tryptophan per litre and with the $\mathrm{pH}$ adjusted to 7.0 with $\mathrm{NaOH}$ was filtersterilized and added at $10 \mathrm{ml}$ per litre of medium where noted. The 10 vitamin supplement was that of Janssen \& Harfoot (1990)

The measurement of succinate and propionate by HPLC, analysis of cytochromes, cell dry mass determinations, and the tests for catalase, oxidase, urease, esculin hydrolysis, and indole production, and the methods for electron microscopy were described by Janssen \& Harfoot (1990). Nitrate reduction was determined as described by Smibert \& Krieg (1981). Sulfide production was tested using a copper precipitation assay (Cord-Ruwisch 1985).

\section{Determination of the $G+C$ content of genomic DNA}

DNA was isolated from cells using 100/G genomic tips (Qiagen, Hilden, Germany), as described by the manufacturer. The purified DNA, in $5 \mathrm{ml}$ QF buffer (Qiagen), was precipitated by the addition of $5 \mathrm{ml} \mathrm{2-}$ propanol, followed by mixing and then centrifugation at $20000 \times g$ for $20 \mathrm{~min}$ at $4{ }^{\circ} \mathrm{C}$. The buffer $/ 2$-propanol mixture was decanted and allowed to drain, and the pellet resuspended in $100 \mu 11.5 \mathrm{mM}$ citrate buffer ( $\mathrm{pH} 7.0$ with $\mathrm{NaOH}$ ) containing $15 \mathrm{mM} \mathrm{NaCl}$. The digestion of the purified DNA, and determination of the mol\% $\mathrm{G}+\mathrm{C}$ ratio were carried out using the following modifications of the methods of Mesbah \& Whitman (1989) and Mesbah et al. (1989). A $50 \mu 1$ sample of a DNA preparation or standard was heated for $2 \mathrm{~min}$ at $100^{\circ} \mathrm{C}$, then cooled immediately in an ice bath. Once cool, $100 \mu 130 \mathrm{mM}$ acetate buffer (pH 5.3 with $\mathrm{NaOH}$ ) and $10 \mu 120 \mathrm{mM} \mathrm{ZnSO}_{4}$ were added, then $10 \mu \mathrm{l}$ of 340 $\mathrm{U}$ nuclease P1 per ml(Sigma, Deisenhofen, Germany; prepared in $30 \mathrm{mM}$ acetate buffer, pH 5.3 with $\mathrm{NaOH}$, containing $0.5 \mathrm{mM} \mathrm{ZnSO} 4$ ). The solution was well mixed, and incubated at $30^{\circ} \mathrm{C}$ for $60 \mathrm{~min}$. After the incubation, $20 \mu 1$ of $500 \mathrm{U}$ alkaline phosphatase per ml(Type VII-NT, Sigma; prepared in $100 \mathrm{mM}$ glycine buffer, pH 10.4 with $\mathrm{NaOH}$ ) was added, and the mixture well mixed. After a further incubation at $37^{\circ} \mathrm{C}$ for $6 \mathrm{~h}, 10 \mu \mathrm{l} 400 \mathrm{mM}$ triethylamine (pH 5.1 with $\mathrm{H}_{3} \mathrm{PO}_{4}$ ) was added.

The nucleosides were separated by reversed-phase HPLC on a Superspher RP18 $(4 \mu \mathrm{m}) 200 \times 4.6 \mathrm{~mm}$ column (Grom, Herrenberg, Germany) with $20 \mathrm{mM}$ triethylamine (pH 5.1 with $\mathrm{H}_{3} \mathrm{PO}_{4}$ ) containing $12 \%(\mathrm{v} / \mathrm{v})$ methanol, at a flow rate of $1 \mathrm{ml}$ per min. The elution of the nucleosides was followed at $270 \mathrm{~nm}$ using a UVIS 204 variable wavelength detector (Linear Instruments, Freemont, California, USA), and the data collected and peaks integrated using Axxiom 747 software (Axxiom, Moorpark, California, USA). Standards of individual bases (Sigma) allowed the detection of contaminating ribonucleosides, and identification of the thymidine and deoxyguanosine peaks. Standard DNAs (Sigma) from Clostridium perfringens, Escherichia coli, and Micrococcus luteus were dissolved at $1 \mathrm{mg}$ per $\mathrm{ml}$ in 1.5 $\mathrm{mM}$ citrate buffer (pH 7.0 with $\mathrm{NaOH}$ and containing $15 \mathrm{mM} \mathrm{NaCl}$ ), and digested and analyzed as described above, and used to prepare a standard curve for deter- 
mination of the mol\% $\mathrm{G}+\mathrm{C}$ ratio of the newly isolated DNA. The mol\% $\mathrm{G}+\mathrm{C}$ ratio was calculated from the integrated areas of the thymidine and deoxyguanosine peaks.

\section{Succinate metabolism}

Cells were harvested by centrifugation under strictly anoxic conditions as previously described (Janssen \& Schink 1993), and washed and resuspended in anoxic $50 \mathrm{mM}$ HEPES buffer ( $\mathrm{pH} 7.0$ with $\mathrm{KOH}$ ), containing $350 \mathrm{mM} \mathrm{KCl}, 10 \mathrm{mM} \mathrm{MgCl}_{2}$ and $2.5 \mathrm{mM}$ dithiothreitol. The cell concentrates were either used to inoculate cell suspension experiments, or used to prepare crude cell-free extracts by French-press treatment (Janssen \& Schink 1993). To prepare cell suspensions, dense cell concentrates were used to inoculate (a final concentration of 30 to $40 \mathrm{mg}$ cell protein per litre) $20 \mathrm{ml}$ volumes of the same buffer containing $20 \mathrm{mM} \mathrm{K}_{2}$-succinate, but with varying amounts of $\mathrm{KCl}$ replaced by $\mathrm{NaCl}$ so that the total concentration of $\mathrm{NaCl}$ plus $\mathrm{KCl}$ was $350 \mathrm{mM}$. This ensured that the osmotic strength in all experiments was equal (Wolf et al. 1987). Succinate turnover was followed by sampling at $15 \mathrm{~min}$ intervals for up to $4 \mathrm{~h}$, and measuring the propionate formed by gas chromatography (Platen \& Schink 1987).

Enzyme assays were carried out at $34^{\circ} \mathrm{C}$ using a 100-40 photometer (Hitachi, Tokyo, Japan) with 1 $\mathrm{ml}$ volumes in $1.5 \mathrm{ml}$ semimicrocuvettes under $\mathrm{N}_{2}$ (Brune \& Schink 1990). Methylmalonyl-CoA decarboxylase (EC 4.1.1.41) was assayed with malonylCoA as substrate as described by Hilpert \& Dimroth (1983). Succinate: propionyl-CoA CoA-transferase (EC 2.8.3.-), and adenosinetriphosphatase (EC 3.6.1.3) were assayed as described by Hilpert et al. (1984). Avidin-treated crude cell-free extracts were incubated anoxically with $250 \mu \mathrm{g}$ avidin per mg extract protein for $60 \mathrm{~min}$ on ice.

Protein was measured colorimetrically (Bradford 1976) with bovine serum albumin as standard. Protein constituted $50 \%$ of the cell dry weight.

\section{Methylmalonyl-CoA decarboxylase in membrane vesicles}

Frozen cells ( $3.6 \mathrm{~g}$ wet weight) were thawed and resuspended in $14 \mathrm{ml}$ of $50 \mathrm{mM}$ potassium phosphate buffer (pH 7.1) containing $1 \mathrm{mM}$ dithioerythritol, $0.1 \mathrm{mM}$ phenylmethanesulfonylfluoride, a trace of deoxyribonuclease, and $0.36 \mathrm{mM} \mathrm{MgCl} 2$. The cells were disrupted by two passages through a French pressure cell at $40 \mathrm{MPa}$, and the buffer volume made up to $30 \mathrm{ml}$. The preparation was centrifuged at $27000 \times g$ for 20 min at $4{ }^{\circ} \mathrm{C}$ to remove unbroken cells and cell debris. The vesicles were sedimented from the supernatant by centrifugation at $140000 \times g$ for $60 \mathrm{~min}$ at $4{ }^{\circ} \mathrm{C}$ in a L8-70 ultracentrifuge (Beckman, München, Germany). The pellet was resuspended in $1 \mathrm{ml} 50 \mathrm{mM}$ potassium phosphate buffer (pH 7.1) and the vesicles again sedimented. The vesicles were then resuspended in $1 \mathrm{ml}$ potassium phosphate buffer, and stored on ice.

The methylmalonyl-CoA decarboxlyase activity in the membrane vesicle preparation was assayed in a $180 \mu \mathrm{l}$ volume in $50 \mathrm{mM}$ potassium phosphate buffer (pH 7.1) containing $30 \mu \mathrm{l}$ vesicle preparation, $1 \mathrm{mM}$ methylmalonyl-CoA, and, as required, $20 \mathrm{mM} \mathrm{NaCl}$. At appropriate time intervals, samples of $60 \mu \mathrm{l}$ were added to $5 \mu \mathrm{l} 70 \%(\mathrm{w} / \mathrm{v})$ perchloric acid, centrifuged to removed the precipitate, and $50 \mu \mathrm{l}$ of the supernatant added to $450 \mu 1200 \mathrm{mM}$ potassium phosphate buffer (pH 5.0), and neutralized with $2 \mu 110 \mathrm{M} \mathrm{NaOH}$. Methylmalonyl-CoA and propionyl-CoA were determined by HPLC (Hilbi \& Dimroth 1994). Parallel experiments were used to analyse the $\mathrm{Na}^{+}$concentration by atomic absorption spectroscopy at 588.9 $\mathrm{nm}$ with an AA646 atomic absorption/flame emission spectrophotometer (Shimadzu, Kyoto, Japan). This showed the background $\mathrm{Na}^{+}$concentration in the assays (without added $\mathrm{NaCl}$ ) to be $28 \mu \mathrm{M}$.

\section{Phylogenetic analysis}

DNA isolation, PCR-mediated amplification of the almost complete $16 \mathrm{~S}$ rRNA gene, and sequence analysis were performed as described by Liesack \& Finster (1994). The 16S rRNA sequence of strain 9succ1 was manually aligned and compared with reference sequences selected from a database containing about 1800 eubacterial sequences (Neefs et al. 1993; Maidak et al. 1994). The phylogenetic position of strain 9succ 1 was deduced by comparing its $16 \mathrm{~S}$ rDNA sequence with various representatives of the main branches of the empire Eubacteria (Trüper 1994). Levels of sequence similarity were calculated by comparing only those positions at which bases could be aligned unambiguously (870 nucleotide positions). Evolutionary distances between pairs of microorganisms were determined using the Jukes-Cantor equation (Jukes \& Cantor 1969) implemented in the 'DNADIST' program of the 'PHYLIP' v.3.5 package (Felsenstein 1989). A tree estimating the phylogenetic relationships was derived using the 'FITCH' program of the same pack- 
age, with a random-order input of sequences, and the global rearrangement option.

\section{Nucleotide sequence accession numbers}

The 16S rDNA sequence of strain 9succ1 has been deposited in the EMBL, GenBank, and DDBJ nucleotide sequence databases under the accession number X90471. The EMBL and Genbank data base accession numbers for sequences used as references in phylogenetic treeing (Fig. 7) are as follows: Propionigenium modestum: X54275; Propionigenium maris: X84049; Fusobacterium nucleatum: X55401;Clostridium butyricum: M59085; Clostridium histolyticum: M59094; Clostridium perfringens: M69264; Selenomonas ruminantium: M62702; Phascolarctobacteriumfaecium: X72865; Succiniclasticum ruminis: X81137; Veillonella parvula: X84005; Sporomusa paucivorans: M59117; Sporomusa termitida: M61920; Helcococcus kunzii: X69837; Escherichia coli: J01695. The following sequences were obtained from the DNA Data Bank of Japan: Peptostreptococcus asaccharolyticus: D14138; Peptostreptococcus indolicus: D14147; Peptostreptococcus magnus: D14149; Peptostreptococcus micros: D14143.

\section{Peptidoglycan analysis}

Preparation of cell walls and determination of the peptidoglycan structure was carried out by the methods of Schleifer \& Kandler (1972), modified by using thin layer chromatography on cellulose sheets instead of paper chromatography. Briefly, $1 \mathrm{mg}$ of freeze-dried cell wall material was hydrolyzed in $0.2 \mathrm{ml}$ of $4 \mathrm{M}$ $\mathrm{HCl}$ at $100^{\circ} \mathrm{C}$ for 16 hours (total hydrolysate) and 45 min (partial hydrolysate). Diamino acids were identified from the total hydrolysate by one-dimensional chromatography using methanol:pyridine:water: $10 \mathrm{M}$ $\mathrm{HCl}(32: 4: 7: 1, \mathrm{v} / \mathrm{v} / \mathrm{v} / \mathrm{v})$. Amino acids and peptides in the partial and total hydrolysates were identified by their mobilities and staining characteristics with ninhydrin spray, after two dimensional chromatography (Schleifer \& Kandler 1972). The resulting "fingerprints" were compared with those of known peptidoglycan structures.

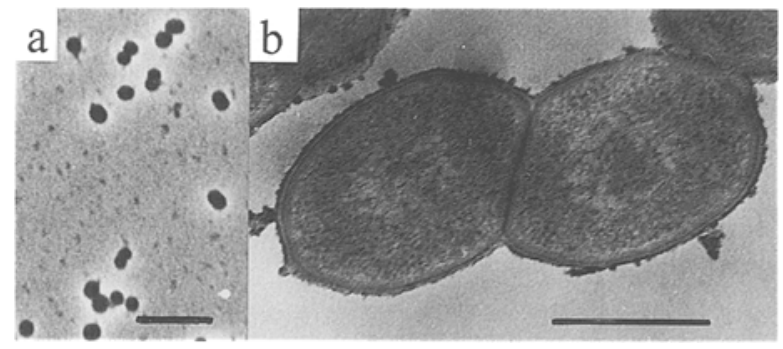

Figure 1. Morphology of strain 9succ1. (a) Phase contrast micrograph. Bar $=5 \mu \mathrm{m}$. (b) Electron micrograph of ultrathin section of strain 9 succl, showing the wall structure and the division point. Bar $=0.5 \mu \mathrm{m}$

\section{Results}

\section{Enrichment and isolation of strain 9 succl}

Enrichment cultures in estuarine medium with $20 \mathrm{mM}$ succinate and $1.0 \mathrm{~g}$ yeast extract per litre were inoculated with sediment from a polluted pond. After 8 days incubation at $34^{\circ} \mathrm{C}$, all of the added succinate had been degraded to propionate. The enrichment cultures were subcultured twice into the same medium, then diluted into agar deep dilution series. Colonies developed within a week, and a pure culture was obtained by dilution of selected colonies into further agar deep series using estuarine medium with $20 \mathrm{mM}$ succinate and $1.0 \mathrm{~g}$ yeast extract per litre. The pure culture obtained from one colony was designated strain 9 succ1. The strain was further cultivated in freshwater medium, using sulfide reductant instead of cysteine/sulfide, and supplemented with $20 \mathrm{mM}$ succinate and $1.0 \mathrm{~g}$ yeast extract per litre.

\section{Morphological and biochemical characteristics}

The cells of strain 9succ1 were cocci, 0.7 to $0.9 \mu \mathrm{m}$ in diameter (Fig 1a), and occurred singly, in pairs or in short chains of up to 6 cells. The cells were non-motile, and negatively-stained whole cell electron micrographs revealed no flagella. No spores were ever observed, even when inoculated into estuarine cooked meat medium. No viable subcultures could be produced from a ten day-old culture after incubation at $80^{\circ} \mathrm{C}$ for 5 minutes. Cells of strain 9succ 1 stained Gram-positive, and thin sections revealed a singlelayered Gram-positive cell wall structure (Fig. 1b). 
Table 1. Substrates tested for growth and fermentation by strain 9succl. Numbers given after each substrate indicate initial concentration $(20 \mathrm{mM}$ unless noted otherwise). Tested in the presence of $1.0 \mathrm{~g}$ yeast extract per litre.

\begin{tabular}{|c|c|}
\hline Substrates supporting growth: & Organic end products ${ }^{a}$ \\
\hline Succinate & propionate \\
\hline Fumarate & malate ${ }^{b}$, acetate, propionate \\
\hline Pyruvate & formate, acetate, butyrate \\
\hline DL-3-Hydroxybutyrate & acetate, butyrate \\
\hline Lysine & acetate, butyrate \\
\hline Yeast extract $\left(1.0 \mathrm{~g} . \mathrm{l}^{-1}\right)$ & acetate, propionate, butyrate ${ }^{c}$ \\
\hline \multicolumn{2}{|l|}{ Substrates not utilized: } \\
\hline \multicolumn{2}{|c|}{$\begin{array}{l}\text { Oxalate, malonate, glutarate, adipate, pimelate, malate, maleate, tartrate, glycolate, } \\
\alpha \text {-ketoglutarate, citrate, DL-lactate, acrylate, formate, DL-2-hydroxybutyrate, ethanol, } \\
\text { ethane-1,2-diol, butane-2,3-diol, acetoin, glucose (5), galactose (5), fructose (5), ribose (5), } \\
\text { xylose (5), maltose (5), lactose (5), sucrose (5), cellobiose (5), mannitol (5), glycerol (5), } \\
\text { sorbitol (5), alanine, arginine, aspartate, threonine, glutamate, cysteine, glycine, tryptophan }\end{array}$} \\
\hline
\end{tabular}

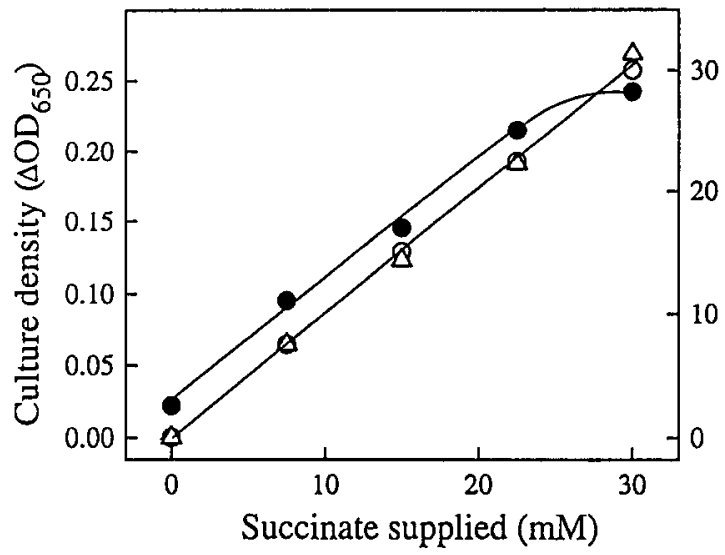

Figure 2. Growth of strain 9 succl on a range of succinate concentrations in the presence of 1.0 g yeast extract per litre. Symbols: $(O)$ succinate degraded, $(\triangle)$ propionate formed, $(\odot)$ culture density at $660 \mathrm{~nm}$

No cytochromes were detected in cell-free extracts of succinate-grown cultures. The $\mathrm{mol} \% \mathrm{G}+\mathrm{C}$ content of the genomic DNA was 29 , as determined by HPLC analysis of hydrolyzed DNA. The peptidoglycan of strain 9succ1 was of the L-ornithine-D-glutamate type.

Strain 9succ 1 was both catalase and oxidase negative. Esculin and urea hydrolysis, indole formation from L-tryptophan, and $\mathrm{H}_{2} \mathrm{~S}$ production from $\mathrm{L}$ cysteine were all negative.

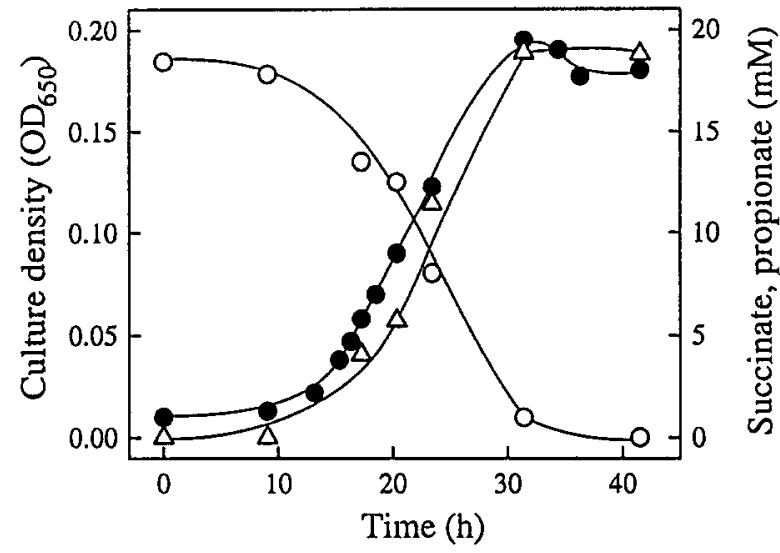

Figure 3. Growth curve of strain 9succ1 on succinate in the presence of $1.0 \mathrm{~g}$ yeast extract per litre. Symbols: $(O)$ succinate, $(\triangle)$ propionate, $(0)$ culture density at $660 \mathrm{~nm}$

\section{Cultural characteristics}

When grown in estuarine medium with $20 \mathrm{mM}$ succinate and $1.0 \mathrm{~g}$ yeast extract per litre, liquid cultures were of white uniform turbidity, but cells tended to lyse after more than 3 weeks. Growth occurred when the medium was not reduced, but was not possible under air. There was no growth when yeast extract was omitted; a 10-vitamin supplement plus an amino acid mixture could not replace the requirement for yeast extract. The optimum temperature for growth 


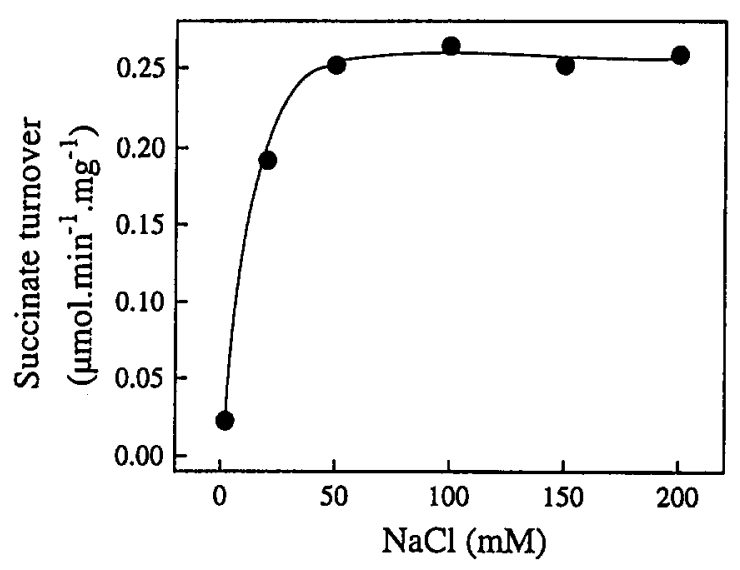

Figure 4. Rate of propionate formation from succinate by strain 9 succl at various $\mathrm{NaCl}$ concentrations. The ionic strength was beld constant at $350 \mathrm{mM} \mathrm{NaCl}$-plus- $\mathrm{KCl}$

was $37^{\circ} \mathrm{C}$. Growth was still possible at $40^{\circ} \mathrm{C}$, but not at $43^{\circ} \mathrm{C}$.

\section{Nutritional characteristics}

Strain 9succ1 grew on a limited range of substrates in the presence of $1.0 \mathrm{~g}$ yeast extract per litre (Table 1). No carbohydrates were fermented and only a limited range of organic and amino acids were utilized: succinate, fumarate, pyruvate, 3-hydroxybutyrate and lysine. Growth on yeast extract alone was poor. There was no growth on $\mathrm{H}_{2}$ plus $\mathrm{CO}_{2}(80: 20$; v:v). When grown on formate plus fumarate there was no utilization of the formate, and the fumarate was fermented as it was when supplied alone. The organic end products of catabolism were formate, acetate, propionate, and butyrate, depending on the substrate. Fumarate was sometimes partly converted to malate.

Nitrate, thiosulfate (each tested with succinate), sulfate or sulfur (each tested with succinate and with lactate) were not reduced.

The growth yield of strain 9succl was proportional to the amount of succinate degraded (Fig. 2). Direct gravimetric determination of the cell dry mass after growth on succinate plus yeast extract, and after growth on yeast extract alone allowed calculation of a molar growth yield of $6.0 \mathrm{~g}$ dry cell mass per mol succinate, at $300 \mathrm{mM} \mathrm{Na}^{+}$. After correction for the end-products formed on yeast extract, $21.3 \mathrm{mmol}$ succinate per litre was degraded to $21.0 \mathrm{mmol}$ propionate per litre (means of 10 independent cultures). The increase in optical density occurred concomitant with succinate degrada-
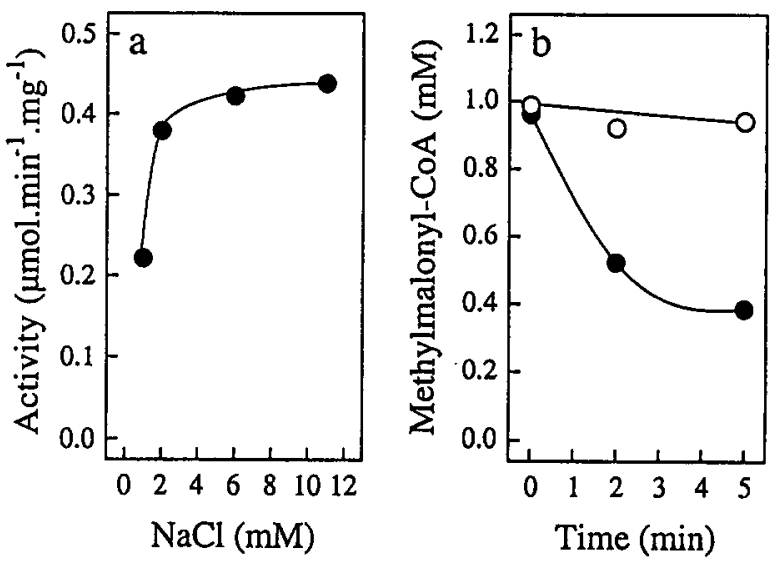

Figure 5. (a) Relationship between methylmalonyl-CoA decarboxlyase activity in a crude cell-free extract of strain 9succ1 and the $\mathrm{NaCl}$ concentration in the assay. (b) Time course of methylmalonylCoA decarboxylation by vesicle preparations of strain 9 succl at low $(\leq 30 \mu \mathrm{M})$ levels of $\mathrm{Na}^{+}(\mathrm{O})$, and at $10 \mathrm{mM}$ added $\mathrm{NaCl}(\odot)$

tion and propionate formation (Fig. 3). Under these conditions ( $\mathrm{pH} \mathrm{7.2,300 \textrm {mM } \mathrm { Na }}+34^{\circ} \mathrm{C}, 1 \mathrm{~g}$ yeast extract per litre), the doubling time was about $4 \mathrm{~h}$ ( $\mu=$ $0.17 \mathrm{~h}^{-1}$ ).

\section{Sodium requirements}

Strain 9succ1 grew over a sodium chloride range of 10 $\mathrm{mM}$ (the lowest tested) to $900 \mathrm{mM}$. The final growth yield was maximal at 300 to $550 \mathrm{mM}$. There was no growth at $1000 \mathrm{mM}$. The growth rate of strain 9succ1 on succinate was independent of sodium ion concentrations between $50 \mathrm{mM}$ and $200 \mathrm{mM}\left(\mu \cong 0.15 \mathrm{~h}^{-1}\right)$, while the growth rate decreased at concentration lower than $50 \mathrm{mM}$ (not shown). Addition of $20 \mu \mathrm{M}$ monensin completely inhibited growth of strain 9 succl at $50 \mathrm{mM} \mathrm{Na}{ }^{+}$with succinate and yeast extract or with 3-hydroxybutyrate plus yeast extract as the growth substrates. Controls to which only ethanol, the solvent for the monensin stock solution, was added showed no growth inhibition. The rate of propionate production from succinate by cell suspensions of strain 9succ1 was lower at low $\mathrm{NaCl}$ concentrations (Fig. 4), even though the buffer was supplemented with $\mathrm{KCl}$ to ensure an equal osmotic strength in all experiments. The rate of succinate metabolism by strain 9 succ1 was maximal at $\mathrm{NaCl}$ concentrations greater than $50 \mathrm{mM}$, and was about $0.25 \mu \mathrm{mol} \cdot \mathrm{min}^{-1} \cdot \mathrm{mg}$ protein $^{-1}$.

Methylmalonyl-CoA decarboxylase (EC 4.1.1.41) at $0.437 \mu \mathrm{mol} \cdot \mathrm{min}^{-1} . \mathrm{mg}$ protein $^{-1}$ (in the pres- 


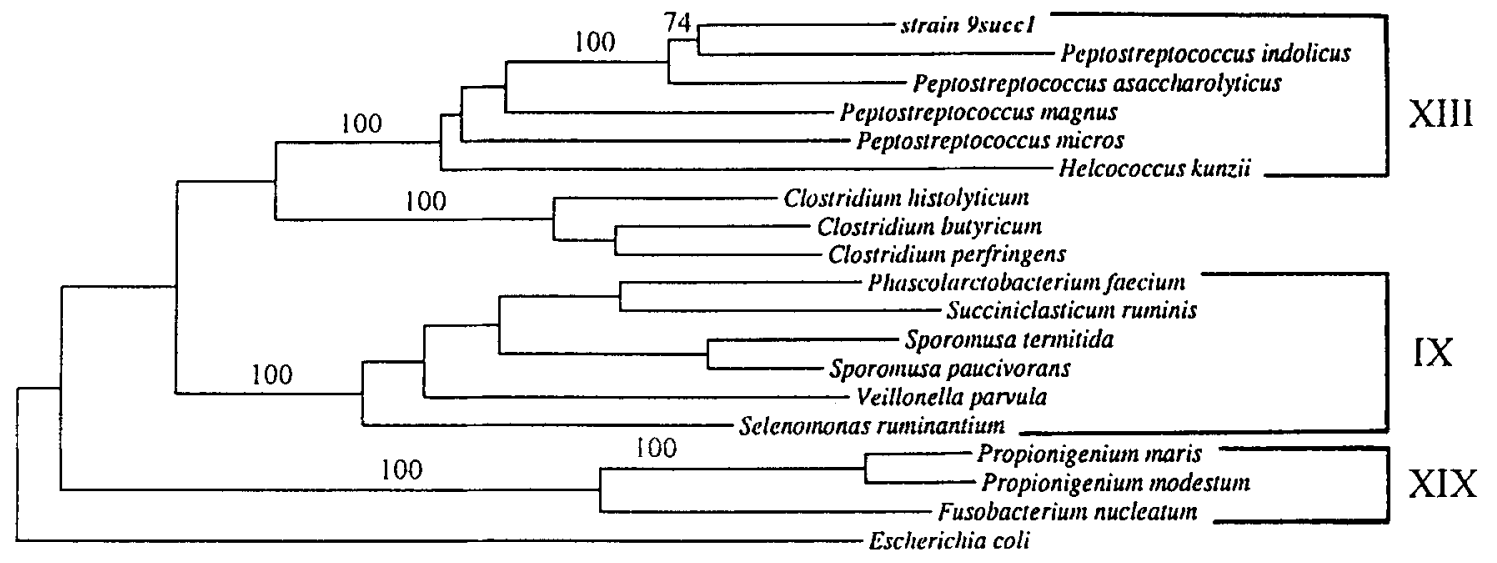

$5 \%$

Figure 6. Phylogenetic tree constructed for strain 9 succl and 17 reference organisms. The 16S rDNA sequence from Escherichia coli was used to root the tree. The numbers indicate the significance (percentage of outcomes) of the branching points as derived from a bootstrap analysis of 1000 replicas using the neighbour-joining method implemented in "MEGA" (Kumar et al. 1993). Bar = 5\% difference in nucleotide sequences, as determined by measuring the lengths of the horizontal lines connecting two species. The Roman numerals refer to the clusters of Collins et al. (1994)

ence of $10 \mathrm{mM} \mathrm{NaCl}$ ), succinate: propionyl-CoA CoA-transferase (EC 2.8.3.-) at $3.89 \mu \mathrm{mol}^{\mathrm{min}}{ }^{-1}$.mg protein $^{-1}$ and ATPase (EC 3.6.1.3) at 0.126 $\mu$ mol. min $^{-1}$.mg protein ${ }^{-1}$ (in the presence of $2.5 \mathrm{mM}$ $\mathrm{NaCl}$ ) were measured in crude cell-free extracts. The methylmalonyl-CoA decarboxylase activity in crude cell-free extracts was stimulated by the addition of $\mathrm{NaCl}$ (Fig. 5a), and membrane vesicle preparations containing only low levels of $\mathrm{Na}^{+}(\leq 30 \mu \mathrm{M})$ catalyzed virtually no methylmalonyl-CoA decarboxylation without added $\mathrm{NaCl}$ (Fig. 5b). Avidin treatment of crude cell-free extracts completely abolished methylmalonyl-CoA decarboxylase activity.

\section{Phylogenetic analysis}

The nucleotide sequence of almost the complete $16 \mathrm{~S}$ rRNA gene (1405 bases) of strain 9succ 1 was determined. Phylogenetic analysis of strain 9succ1 based on comparative 16S rDNA sequence analysis revealed its membership within the clostridial cluster XIII of Collins et al. (1994). This grouping is characterized by members of the genus Peptostreptococcus and by $\mathrm{Hel}$ cococcus kunzii (Fig. 6). Within this cluster, the species most closely related to strain 9 succ 1 are $P$. asaccharolyticus and $P$. indolicus, as well as $P$. lacrimalis (not shown in Fig. 6).

\section{Discussion}

A new strain of succinate-decarboxylating anaerobe, designated strain 9succ1, was enriched and isolated from a freshwater site using an estuarine medium, although sodium at lower concentrations also supported good growth (see below). Strain 9succ1 had a requirement for yeast extract that could not be replaced by vitamin and amino acid mixtures. The cell yield was proportional to the amount of succinate decarboxylated to propionate, and the utilization of succinate was closely coupled with the increase in cell density. This indicates that succinate decarboxylation served as the energy source for growth. The high, almost stoichiometric, recovery of propionate suggests that components of the yeast extract served as precusors for cell matter. Strain 9 succ 1 fermented succinate in agreement with the following equation $\left[\Delta \mathrm{G}_{0}\right.$ ' value calculated after Thauer et al. (1977)]:

$$
\begin{gathered}
\text { succinate }^{2-}+\mathrm{H}_{2} \mathrm{O} \rightarrow \text { propionate } \\
\Delta \mathrm{G}_{0}^{\prime}=-20.6 \mathrm{~kJ} \cdot \mathrm{mol}(\text { succinate })^{-1}
\end{gathered}
$$

From the specific growth rate and specific growth yield, a succinate turnover rate in growing cultures of $0.24 \mu \mathrm{mol} \cdot \mathrm{min}^{-1} \cdot \mathrm{mg}$ protein ${ }^{-1}$ can be calculated. Both the methylmalonyl-CoA decarboxylase and suc- 
cinate: propionyl-CoA CoA transferase activities measured were high enough to account for this substrate turnover rate. In addition, the succinate turnover rate by cell suspensions at non-limiting sodium concentrations was similar to that in growing cultures, at about 0.25 $\mu \mathrm{mol} \cdot \mathrm{min}^{-1} \cdot \mathrm{mg} \mathrm{protein}^{-1}$. The methylmalonyl-CoA decarboxylase activty in crude cell-free extracts was stimulated by sodium ions. Activity was almost absent in membrane vesicle preparations with $\leq 30 \mu \mathrm{M} \mathrm{Na}^{+}$, but could be stimulated by adding $\mathrm{NaCl}$. Avidin completely inhibited the methylmalonyl-CoA decarboxylase activity. These observations imply the enzyme to be a typical biotin-containing, sodium-translocating methylmalonyl-CoA decarboxylase (Dimroth 1987).

Comparative analysis of the 16S rRNA gene of strain 9succ1 revealed its phylogenetic relationship with the genus Peptostreptococcus, within cluster XIII of Collins et al. (1994). Classification within the genus Peptostreptococcus is supported by its phenotypic similarity to other members of the genus Peptostreptococcus (Holdeman Moore et al. 1986, Ezaki et al. 1992), excluding Peptostreptococcus productus, which is unrelated to other Peptostreptococcus spp. (Collins et al. 1994), and has quite a different morphology and $\mathrm{mol} \% \mathrm{G}+\mathrm{C}$ ratio (Holdeman Moore et al. 1986). The similarites between strain 9succ1 and true Peptostreptococcus spp. include: (i) the coccal morphology of strain 9succ1, shared with all true members of the genus Peptostreptococcus (Holdeman Moore et al. 1986); (ii) the single-layered cell wall with a thick peptidoglycan layer; (iii) a peptidoglycan of the Lornithine-D-glutamic acid type; (iv) a mol\% G+C ratio of 29, comparable to that of other true members of the genus, which have mol\% $\mathrm{G}+\mathrm{C}$ ratios of 27 to 35 ; (v) the production of acetate and butyrate as fermentation end products, typical of Peptostreptococcus species; and (vi) the inability to use carbohydrates as growth substrates.

Previously described bacteria able to grow or generate ATP coupled to the free energy change of succinate decarboxylation belong either to the FusobacteriumPropionigenium line of decent [cluster XIX of Collins et al. (1994)], or to the group of Gram-positive bacteria with a Gram-negative cell wall structure [cluster IX of Collins et al. (1994)]. Members of the genus Peptostreptococcus are, however, not known to grow by decarboxylation of succinate (Holdeman Moore et al. 1986, Ezaki et al. 1992). In strain 9succ1, the decarboxylation of succinate is apparently coupled to energy conservation by a biotin-containing, sodiumpumping methylmalonyl-CoA decarboxylase, as has been shown to occur in Propionigenium modestum (Hilpert et al. 1984) and Veillonella parvula (Hilpert \& Dimroth 1983). This, thus, represents a new mechanism of energy conservation within the genus Peptostreptococcus, although ATP synthesis via a sodium gradient generated by decarboxylation of glutaconylCoA during glutamate catabolism by Peptostreptococcus asaccharolyticus has been documented (Wohlfarth \& Buckel 1985). Some transport processes are sodium dependent (Chen \& Russell 1989, Beck \& Russell 1994). Further investigations may well reveal a wide range of sodium-dependent processes within this genus.

The rate of succinate decarboxylation and the growth rate were dependent on the concentration of sodium; at sodium concentrations lower than $50 \mathrm{mM}$, the rate of succinate decarboxylation and the growth rate were both low. This could be the result of: (i) a sodium dependence of succinate import or propionate export, or both; (ii) a requirement for sodium by the methylmalonyl-CoA decarboxylase; or (iii) a requirement for sodium by an ATPase. The methylmalonylCoA decarboxylase of strain 9succ1 showed maximum activity at about 5 to $10 \mathrm{mM} \mathrm{NaCl}$. Similarly, the methylmalonyl-CoA decarboxylases of Propionigenium modestum and Veillonella parvula are also sodiumpumping decarboxylases, requiring about $1 \mathrm{mM}$ and 5 $\mathrm{mM} \mathrm{Na}^{+}$for maximum activity, respectively (Hilpert et al. 1984, Hilpert \& Dimroth 1983). In addition; the ATPase of Propionigenium modestum is stimulated by sodium, and maximal activity requires at least $2 \mathrm{mM} \mathrm{Na}^{+}$(Hilpert et al. 1984, Laubinger \& Dimroth 1988). The transport of succinate by sodium symport has been reported to occur in Selenomonas ruminantium (Michel \& Macy 1990), but this has been questioned in another study (Strobel \& Russell 1991). Amino acid transport has been shown to be driven by transmembrane sodium gradients in Peptostreptococcus spp. (Chen \& Russell 1989, Beck \& Russell 1994). An alternative mechanism of succinate transport in strain 9succl could be a substrate-product antiport system (Anantharam et al. 1989, Konings et al. 1994).

Strain 9succ1 has been deposited with the Deutsche Sammlung von Mikroorganismen und Zellkulturen, Braunschweig, Germany, under the accession number DSM 9536. 


\section{Acknowledgements}

Peter H. Janssen was supported by a UGC scholarship in New Zealand, and by a fellowship from the Alexander von Humboldt-Stiftung in Germany. The use of facilities in the Thermophile Research Unit and the Meat Industry Research Institute of New Zealand (Hamilton), and the hospitality provided by Prof. Dr. Peter Dimroth (Zürich) are gratefully acknowledged. The authors thank Colin Monk (Hamilton) and Sonja Fleissner (Marburg) for their assistance, Dr. Norbert Weiss (Braunschweig) for carrying out the peptidoglycan analysis, Bernd Kreke (Konstanz) for carrying out some of the sodium determinations, and Dr Gregory M. Cook (London) for valuable discussion. Parts of this work were carried out as part of a DPhil thesis by Peter H. Janssen.

\section{References}

Anantharam V, Allison MJ \& Maloney PC (1989) Oxalate: formate exchange. The basis for energy coupling in Oxalobacter. J. Biol. Chem. 264: 7244-7250

Beatrix B, Bendrat K, Rospert S \& Buckel W (1990) The biotindependent sodium ion pump glutaconyl-CoA decarboxylase from Fusobacterium nucleatum (subsp. nucleatum). Arch. Microbiol. 154: $362-369$

Beck BJ \& Russell JB (1994) Electrogenic glutamine uptake by Peptostreptococcus anaerobius and generation of a transmembrane potential. Appl. Environ. Microbiol. 176: 1303-1308

Bradford MM (1976) A rapid and sensitive method for the quantitation of microgram quantities of protein utilizing the principle of protein-dye binding. Anal. Biochem. 72: 248-254

Breznak JA, Switzer JM \& Seitz HJ (1988) Sporomusa termitida sp. nov., an $\mathrm{H}_{2} / \mathrm{CO}_{2}$-utilizing acetogen isolated from termites. Arch. Microbiol. 150: 282-288

Brune A \& Schink B (1990) A complete citric acid cycle in assimilatory metabolism of Pelobacter acidigallici, a strictly anaerobic, fermenting bacterium. Arch. Microbiol. 154: 394-399

Chen G, Russell JB (1989) Sodium-dependent transport of branchedchain amino acids by a monensin-sensitive ruminal peptosteptococcus. Appl. Environ. Microbiol. 55: 2658-2663

Collins MD, Lawson PA, Willems A, Cordoba JJ, FernandezGarayzabal J, Garcia P, Cai J, Hippe H \& Farrow JAE (1994) The phylogeny of the genus Clostridium: proposal of five new genera and eleven new species combinations. Int. J. Syst. Bacteriol. 44: 812-826

Cord-Ruwisch R (1985) A quick method for the determination of dissolved and precipitated sulfides in cultures of sulfate reducing bacteria. J. Microbiol. Meth. 4: 33-36

Dehning I, Stieb M \& Schink B (1989) Sporomusa malonica sp. nov., a homoacetogenic bacterium growing by decarboxylation of malonate or succinate. Arch. Microbiol. 151: 421-426

Del Dot T, Osawa R \& Stackebrandt E (1993) Phascolarctobacterium faecium gen. nov., spec. nov., a novel taxon of the Sporomusa group of bacteria. Syst. Appl. Microbiol. 16: 380-384
Dimroth P (1987) Sodium ion transport decarboxylases and other aspects of sodium ion cycling in bacteria. Microbiol. Rev. 51: 320-340

Ezaki T, Oyaizu H \& Yabuuchi E (1992) The anaerobic grampositive cocci. In: Balows A, Trüper HG, Dworkin M, Harder W \& Schleifer KH (Eds) The Prokaryotes, 2nd edition (pp 18791982). Springer Verlag, New York

Felsenstein J (1989) PHYLIP-phylogeny inference package (version 3.2). Cladistics 5: 164-166

Guangsheng C, Plugge CM, Roelofsen W, Houwen FP \& Stams AJM (1992) Selenomonas acidaminovorans sp. nov., a versatile thermophilic proton-reducing anaerobe able to grow by decarboxylation of succinate to propionate. Arch. Microbiol. 157: 169-175

Hilbi H \& Dimroth P (1994) Purification and characterization of a cytoplasmic enzyme component of the $\mathrm{Na}^{+}$-activated malonate decarboxylase system of Malonomonas rubra: acetyl-S-acyl carrier protein: malonate acyl carrier protein-SH transferase. Arch. Microbiol. 162: 48-56

Hilpert W \& Dimroth P (1983) Purification and characterization of a new sodium-transport decarboxylase. Methylmalonyl-CoA decarboxylase from Veillonella alcalescens. Eur. J. Biochem. 132: $579-587$

Hilpert W, Schink B \& Dimroth P (1984) Life by a new decarboxylation-dependent energy conservation mechanism with $\mathrm{Na}^{+}$as coupling ion. EMBO J. 3: 1665-1670

Holdeman Moore LV, Johnson JL \& Moore WEC (1986) Genus Peptostreptococcus. In: Sneath PHA, Mair MS, Sharpe ME \& Holt JE (Eds) Bergey's Manual of Systematic Bacteriology, vol. 2 (pp 1083-1092). Williams and Wilkins, Baltimore

Hudson JA, Schofield KM, Morgan HW \& Daniel RM (1989) Thermonema lapsum gen. nov., sp. nov., a thermophilic gliding bacterium. Int. J. Syst. Bacteriol. 39: 485-487

Janssen PH (1992) Growth yield increase and ATP formation linked to succinate decarboxylation in Veillonella parvula. Arch. Microbiol. 157: $442-445$

Janssen PH \& Harfoot CG (1990) Isolation of a Citrobacter species able to grow on malonate under strictly anaerobic conditions. J. Gen. Microbiol. 136: 1037-1042

Janssen PH \& Liesack W (1995) Succinate decarboxylation by $P r o-$ pionigenium maris sp. nov., a new anaerobic bacterium from an estuarine sediment. Arch. Microbiol. 164: 29-35

Janssen PH \& Schink B (1993) Pathway of anaerobic poly-Bhydroxybutyrate degradation by Ilyobacter delafieldii. Biodegradation 4: 179-185

Jukes TH \& Cantor CR (1969) Evolution of protein molecules. In: Munro HN (Ed) Mammalian Protein Metabolism, vol. 3 (pp 21132). Academic Press, New York

Konings WN, Poolman B \& van Veen HW (1994) Solute transport and energy transduction in bacteria. Antonie van Leeuwenhoek 65: $369-380$

Kumar S, Tamura K \& Nei M (1993) MEGA: molecular evolutionary genetic analysis, version 1.0. Pennsylvania State University Park, USA

Laubinger W \& Dimroth P (1988) Characterization of the ATP synthase of Propionigenium modestum as a primary sodium pump. Biochemistry 27: 7531-7537

Laubinger W \& Dimroth P (1989) The sodium ion translocating adenosinetriphosphatase of Propionigenium modestum pumps protons at low sodium ion concentrations. Biochemistry 28: 7194-7198

Liesack W \& Finster K (1994) Phylogenetic analysis of five strains of gram-negative, obligately anaerobic, sulfur-reducing bacteria and description of Desulfuromusa gen. nov., including Desulfuromusa kysingii sp. nov., Desulfuromusa bakii sp. nov., and 
Desulfuromusa succinoxidans sp. nov. Int. J. Syst. Bacteriol. 44: 753-758

Maidak BL, Larsen N, McCaughey MJ, Overbeek R, Olsen GJ, Fogel K, Blandy J \& Woese CR (1994) The ribosomal database project. Nucl. Acids Res. 22: 3485-3487

Mesbah M \& Whitman WB (1989) Measurement of deoxyguanosine/thymidine ratios in complex mixtures by high-performance liquid chromatography for determination of the mole percentage guanine + cytosine of DNA. J. Chromatogr. 479: 297-306

Mesbah M, Premachandran U \& Whitman WB (1989) Precise measurement of the $\mathrm{G}+\mathrm{C}$ content of deoxyribonucleic acid by highperformance liquid chromatography. Int. J. Syst. Bacteriol. 39: 159-167

Michel TA \& Macy JM (1990) Generation of a membrane potential by sodium-dependent succinate efflux in Selenomonas ruminantium. J. Bacteriol. 172: 1430-1435

Neefs JM, Van de Peer Y, De Rijk P, Chapelle S \& De Wachter R (1993) Compilation of small ribosomal subunit RNA structures. Nucl. Acids Res. 21: 3025-3049

Ollivier B, Cord-Ruwisch R, Lombardo A \& Garcia JL (1985) Isolation and characterization of Sporomusa acidovorans sp. nov., a methylotrophic homoacetogenic bacterium. Arch. Microbiol. 142: 307-310

Osawa R, Fujisawa T \& Mitsuoka T (1992) Characterization of gram-negative anaerobic strains, isolated from koala feces, which exhibit satellite growth and pleomorphism. Syst. Appl. Microbiol. 15: $628-635$

Pfennig N (1978) Rhodocyclus purpureus gen. nov., sp. nov., a ring-shaped, vitamin $\mathrm{B}_{12}$-requiring member of the family Rhodospirillaceae. Int. J. Syst. Bacteriol. 28: 283-288

Platen H \& Schink B (1987) Methanogenic degradation of acetone by an enrichment culture. Arch. Microbiol. 149: 136-141

Scheifinger CC \& Wolin MJ (1973) Propionate formation from cellulose and soluble sugars by combined cultures of Bacteroides succinogenes and Selenomonas ruminantium. Appl. Microbiol. 26: 789-795

Schink B \& Pfennig N (1982) Propionigenium modestum gen. nov. sp. nov., a new strictly anaerobic, nonsporing bacterium growing on succinate. Arch. Microbiol. 133: 209-216
Schink B (1992) The genus Propionigenium. In: Balows A, Trüper HG, Dworkin M, Harder W \& Schleifer KH (Eds) The Prokaryotes, 2nd edition (pp 3948-3951). Springer-Verlag, New York

Schleifer KH \& Kandler O (1972) Peptidoglycan types of bacterial cell walls and their taxonomic implications. Bacteriol. Rev. 36; 407-477

Smibert RM \& Krieg NR (1981) General characterization. In: Gerhardt P, Murray RGE, Costilow RN, Nester EW, Wood WA, Krieg NR \& Phillips GB (Eds) Manual of Methods for General Bacteriology (pp 409-443). American Society for Microbiology, Washington, DC

Strobel HJ \& Russell JB (1991) Succinate transport by a ruminal selenomonad and its regulation by carbohydrate availability and osmotic strength. Appl. Environ. Microbiol. 57: 248-254

Thauer RK, Jungermann K \& Decker K (1977) Energy conservation in chemotrophic anaerobic bacteria. Bacteriol. Rev. 41: 100-180

Trüper HG (1994) Taxonomic note: names for the higher taxa and their impact on the code of nomenclature of bacteria. Int. J. Syst. Bacteriol. 44: 368-369

van Gylswyk NO (1995) Succiniclasticum ruminis gen. nov., sp. nov., a ruminal bacterium converting succinate to propionate as the sole energy-yielding mechanism. Int. J. Syst. Bacteriol. 45: 297-300

Willems A, Collins MD (1995) Phylogenetic placement of Dialister pneumosintes (formerly Bacteroides pneumosintes) within the Sporomusa subbranch of the Clostridium subphylum. Int. J. Syst. Bacteriol. 45: 403-405

Wohlfarth G \& Buckel W (1985) A sodium ion gradient as energy source for Peptostreptococcus asaccharolyticus. Arch. Microbiol. 142: $128-135$

Wolf AV, Brown MG \& Prentiss PG (1987) Concentrative properties of aqueous solutions: conversion tables. In: Weast RC, Astle MJ, Beyer W (Eds) CRC Handbook of Chemistry and Physics, 68th edition (pp D219-D271). CRC Press, Boca Raton, Florida, USA 